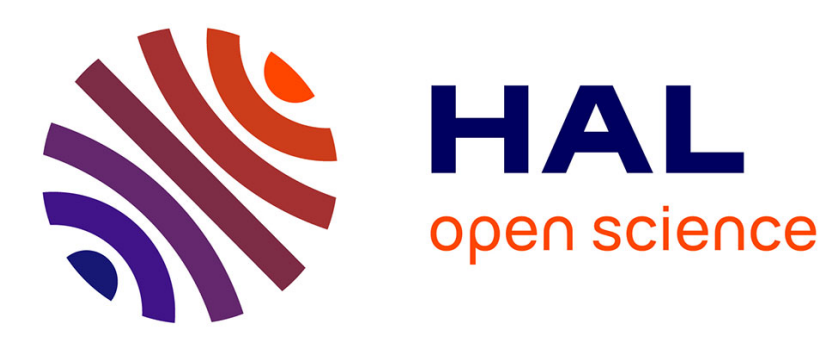

\title{
MOLECULAR CYTOGENETICS OF LYMPHOMA. WHERE DO WE STAND IN 2010?
}

\author{
Philip M Kluin, Ed Schuuring
}

\section{To cite this version:}

Philip M Kluin, Ed Schuuring. MOLECULAR CYTOGENETICS OF LYMPHOMA. WHERE DO WE STAND IN 2010?. Histopathology, 2011, 58 (1), pp.128. 10.1111/j.1365-2559.2010.03700.x . hal-00610743

\section{HAL Id: hal-00610743 \\ https://hal.science/hal-00610743}

Submitted on 24 Jul 2011

HAL is a multi-disciplinary open access archive for the deposit and dissemination of scientific research documents, whether they are published or not. The documents may come from teaching and research institutions in France or abroad, or from public or private research centers.
L'archive ouverte pluridisciplinaire HAL, est destinée au dépôt et à la diffusion de documents scientifiques de niveau recherche, publiés ou non, émanant des établissements d'enseignement et de recherche français ou étrangers, des laboratoires publics ou privés. 


\section{Histopathology}

MOLECULAR CYTOGENETICS OF LYMPHOMA. WHERE DO WE STAND IN 2010?

\begin{tabular}{|r|l|}
\hline Journal: & Histopathology \\
\hline Manuscript ID: & HISTOP-08-10-0472.R1 \\
\hline Wiley - Manuscript type: & Review \\
\hline Aute Submitted by the & 06-Oct-2010 \\
\hline Complete List of Authors: & $\begin{array}{l}\text { Kluin, Philip; University Medical Centre Groningen, Pathology and } \\
\text { Medical Biology } \\
\text { Schuuring, Ed; University Medical Centre Groningen, Pathology and } \\
\text { Medical Biology }\end{array}$ \\
\hline Keywords: & lymphoma, review, genetic, translocation, cytogenetics \\
\hline \multicolumn{2}{|c}{} \\
\hline
\end{tabular}

\section{SCHOLARONE" Manuscripts}


MOLECULAR CYTOGENETICS OF LYMPHOMA. WHERE DO WE STAND IN 2010?

Philip Kluin, MD PhD, pathologist

Ed Schuuring, PhD, molecular-biologist

Dept of Pathology and Medical Biology

University Medical Centre Groningen, UMCG, University of Groningen The Netherlands

Tel +31503611766/3616161

Email p.m.kluin@path.umcg.nl

Running head: molecular genetics of lymphoma

Key words: lymphoma, cytogenetics, review 


\begin{abstract}
For the past 20 years most malignant lymphomas have been classified as clinico-pathologic entities, each with its own combination of clinical, morphologic, immunophenotypic and molecular genetic characteristics. Molecular and cytogenetic abnormalities can be detected by a wide range of techniques, ranging from conventional karyotyping to single nucleotide polymorphism analysis. In this review, we consider the common genetic abnormalities found in lymphoma and discuss the advantages and disadvantage of individual techniques used in their detection. Finally, the authors briefly discuss possible novel developments in the field of lymphoma diagnostics.
\end{abstract}




\section{Introduction}

During the past two decades molecular diagnostics have become an integral part of the laboratory repertoire in haematopathology. Conventional and molecular cytogenetic techniques are used to detect recurrent chromosomal translocations or breakpoints, as well as specific deletions, gains and point mutations. These abnormalities may be used in the primary classification of a tumour or as prognostic factors. This review aims to give an overview of the currently available molecular and cytogenetic methods, the lymphoma specific targets that can be analyzed by these methods and to provide guidelines for their use in everyday practice. The important molecular abnormalities found in the common types mature $\mathrm{B}$ and $\mathrm{T}$ cell lymphomas as known in $2010^{1}$ are shown in table 2

\section{Molecular cytogenetic methods.}

\section{Karyotype analysis / classical cytogenetics.}

Only three years after the discovery of the Philadelphia chromosome in $1960,{ }^{2}$ the first recurrent cytogenetic abnormalities were described in Burkitt lymphoma. ${ }^{3}$ This was later found to be the classical translocation $\mathrm{t}(8 ; 14)(\mathrm{q} 24 ; \mathrm{q} 32)$ in which the $M Y C$ gene and immunoglobulin heavy chain gene $(I G H)$ complex are involved. This was followed by the discovery of many more recurrent chromosomal translocations. Some of these chromosomal translocations are considered as the diagnostic hallmark of specific disease entities, whereas others may be secondary and involved in tumour progression. ${ }^{4}$ Recurrent translocations can be detected in $>90 \%$ of the cases of Burkitt lymphoma, mantle cell lymphoma and follicular lymphoma grade 1 and 2, and are considered as the cancer initiating events in these diseases. In other lymphomas, and in particular in diffuse large B cell lymphoma, multiple breakpoints and translocations with a plethora of numerical abnormalities (gains and losses) are seen. In these cases it is often impossible to decide which events are involved in the primary initiation and subsequent progression of the tumour.

A good example of this complexity is the involvement of $M Y C$ and the 8q24 breakpoint in lymphomagenesis. MYC rearrangements are widely regarded as the primary event in Burkitt lymphoma (the $\mathrm{t}(8 ; 14)$ or variant $\mathrm{t}(2 ; 8)(\mathrm{p} 12 ; \mathrm{q} 24)$ and $\mathrm{t}(8 ; 22)(\mathrm{q} 24 ; \mathrm{q} 11)$ translocations), but $M Y C$ is also frequently involved in tumour progression, either by chromosomal translocation, gain or amplification in other types of lymphoma.. Rearrangements of $M Y C$ can be found in 
5-20\% of diffuse large B cell lymphoma. In more than half of these cases additional abnormalities, most commonly the $\mathrm{t}(14 ; 18)$, can be identified. These "double-hit" or "dualhit" lymphomas ${ }^{5-10}$ often have complex cytogenetic alterations including occasional breakpoints at 3q27/BCL6 ("triple hit" lymphomas). This complexity can be best detected by conventional cytogenetics, since it represents a genome wide method by which many structural and numerical abnormalities can be simultaneously detected, albeit at a low resolution.

The genome wide scope of conventional cytogenetic analysis means that it is often considered to be the "gold standard" for lymphoma diagnostics raising the question as to why is it not part of routine practice. Several logistic and technical problems hamper the routine use of this method. These include the need to obtain fresh tumour tissue which must be processed within few hours after removal from the patient, the need for a relatively large volume of tissue, and the high level of skill required to culture the lymphoma cells, to prepare high quality metaphase cells, and to analyse the often complex karyograms. This makes the method labour intensive, time-consuming and expensive. Moreover, the failure rate is relatively high. In particular in indolent lymphomas and myelomas the tumour cells may fail to grow in culture only normal karyotypes may be seen.

Given these problems the possibility that fluorescent in situ hybridization (FISH) or other methods could completely replace conventional cytogenetics needs to be considered. FISH is a rapid, robust, cheap and relatively easily applicable technique that can be applied to formalin fixed and paraffin embedded (FFPE) tissues and does not need vital, growing cells or specific culture systems (Table 1). ${ }^{11,12}$ A further advantage is a short turnaround time which is usually in the order of 2 or 3 workings days. The major limitation of FISH is that is targeted to the detection of specific abnormalities and the genome wide perspective offered by conventional cytogenetics is lost. This may be clinically important as additional aberrations (or their absence) can be diagnostic or predictive for the course of disease (see Table 2). For example, the diagnosis of Burkitt lymphoma depends not only on the presence of a $M Y C$ or $8 q 24$ breakpoint in Burkitt lymphoma, but on the absence of complex genomic complexity abnormalities. $30-40 \%$ of all Burkitt lymphoma cases harbour only the $t(8 ; 14)$ or its variants, the rest exhibiting only one to two additional abnormalities (mostly alterations at 1q, trisomy7, trisomy 12 or alterations at $13 q$ involving the microRNA 17-92 cluster) are found. ${ }^{4}$ ${ }^{13,14}$ In contrast, the genomic complexity in DLBCL with an $8 \mathrm{q} 24$ breakpoint is usually much 
higher. ${ }^{13,15-17}$. In a recent study of aggressive B cell lymphomas with a MYC-IG breakpoint, 22 Burkitt lymphomas had a mean of 1,7 additional conventional cytogenetic abnormalities, whereas 12 other (non Burkitt) lymphomas with a MYC-IG breakpoint had a mean of 8.8 abnormalities with three DLBCL showing over 21 ,cytogenetic abnormalities. ${ }^{16}$ In another study using FISH and array CGH on a large series of lymphomas, an almost similar genomic complexity of 2 additional abnormalities in the 39 molecular Burkitt lymphomas versus 9 in the 35 other aggressive B cell lymphomas with a $M Y C$ breakpoint was observed. ${ }^{15}$ Based on this data in Burkitt lymphoma and DLBCL, it now seems justifiable to regard the presence of a complex karyotype with a $(8 ; 14)$ as a diagnostic criteria for distinguishing Burkitt Lymphoma from Diffuse Large B-cell Lymphoma. The importance of this distinction argues for the retention of techniques that provide a genome wide survey of genetic abnormalities lymphoma.

An intrinsic problem with conventional cytogenetic analysis is that the resolution offered by banding techniques is low at approximately 4-5 Mb (Table 1). This means that structural alterations like translocation breakpoints may look similar at the light microscopic level but are different at the molecular level. For instance approximately $15 \%$ of all myelomas contain a $\mathrm{t}(11 ; 14)(\mathrm{q} 13 ; \mathrm{q} 32)$ which appears identical to the characteristic translocation seen in mantle cell lymphoma. However, at the molecular level the breakpoint in myeloma affects the $I G H$ locus at switch regions instead of the VDJ complex in mantle cell lymphoma and thus imply a different cellular origin. ${ }^{18,19}$

In spite of these limitations conventional cytogenetics remains a useful method to detect both specific primary and secondary abnormalities and an overall assessment of genetic complexity in lymphomas. It remains a valuable method to find new recurrent abnormalitie and the systematic collection of data in the Mitelman database, which in July 2010 contained karyotypic data of 7583 mature B cell and 1265 mature T cell lymphoma cases, is a highly valuable source for data-mining (http://cgap.nci.nih.gov/Chromosomes/Mitelman).

\section{Multicolour fluorescent in situ hybridization (FISH) on chromosomes.}

A ability of conventional metaphase cytogenetics to detect genome-wide genetic changes has been expanded by the introduction of multicolour painting of chromosomal preparations, by multiplex FISH, spectral karyotyping or COBRA FISH (combined binary ratio labelling 
FISH). ${ }^{20-24}$ In these methods multiple labels (up to > 50) are generated by using mixtures of different fluorochromes. These labels are used to generate probes to multiple genomic regions including individual chromosomes or long and short chromosomal arms.are labelled with such mixtures. These labelled genomic sequences are subsequently hybridized to a metaphase chromosome preparations. Complex structural abnormalities can be visualized readily and the chromosomal origin of abnormal structures like marker chromosomes can be identified much more easily than by conventional cytogenetics. However, these methods require specific interpretative skills and more complex equipment than conventional cytogenetics, and therefore are only accessible to limited number of investigators.

3. Conventional comparative genomic hybridization $(\mathrm{CGH})$ and array comparative genomic hybridization (aCGH)

Genome wide methods that do not need dividing tumour cells are comparative genetic hybridization $(\mathrm{CGH})^{25-27}$ and its successor array CGH (aCGH). The principles of both methods are shown in Figure 1. A major drawback of both techniques is that balanced chromosomal alterations like translocations cannot be detected. Conventional CGH is based on a competitive hybridization between normal (for instance Cy3-labeled) DNA and tumour cell derived (for instance Cy5-labeled) DNA, where chromosomes obtained from normal individuals are used as a template for hybridisation. Thus the availability and quality of normal chromosome preparations may be a limiting factor. Moreover, the resolution is not much better than of conventional cytogenetics (Table 1).

Conventional CGH has been replaced by array CGH or "matrix CGH" in which the DNA fragments used for competitive hybridization are spotted on a glass slide and not on normal chromosomes. Depending on the number of (overlapping) probes used to create the platform, aCGH has a very high resolution at less than 50-100 kb. DNA isolated from paraffin tissue blocks can be successfully used for hybridization. Up to now approximately 65 publications have appeared on the application of array CGH in mature B cell and T cell lymphomas. ${ }^{28-34}$ and these show distinct patterns of gains and losses characteristic of particular lymphoma subtypes. Within the group of DLBCL, activated B cell (ABC) type DLBCL have a different pattern from germinal centre B cell (GCB) type DLBCL, with recurrent trisomy 3, gain of 18q and $19 q$, as well as loss of $6 q$ in ABC type and gain/amplification of $2 p$ and loss of $1 p$ and $13 q$ in GCB type of DLBCL as well as frequent gain/amplification of 9p in primary 
mediastinal type of lymphomas (Table 2). ${ }^{35}$ Similarly, distinct features were found between different types of $\mathrm{T}$ cell lymphomas.

\section{Single nucleotide polymorphism (SNP) analysis.}

SNP analysis is the most recently introduced whole genome method and has the potential advantage of an even higher resolution. ${ }^{36,37}$ Figure 2 illustrates the analysis of a series of paediatric BL using either aCGH ( $n=15$; figure $2 \mathrm{~A})$ or SNP analysis $(n=18$; figure $2 \mathrm{~B})$ (Kluin et al, unpublished data). The higher resolution with SNP analysis is also shown in Figure 2C, in which we encountered a homozygous deletion at chromosome 9p21 affecting CDKN4 and CDKN6, two important tumour suppressor genes, that was missed by both conventional and array based CGH analysis. A unique advantage of SNP analysis over all other methods is that not only changes in copy number but also regions of loss of heterozygosity without loss or gain of DNA can be detected, indicating that both alleles are homozygous and derived from one parent. This loss of heterozygosity without changes in copy numbers is called uniparental disomy (UPD). ${ }^{38-42}$ UPD may be important to detect since regions of UPD may harbour one or more genes with inactivating mutations (classical tumour suppressor genes). Since in a region with UPD both alleles will have the mutation, the Knudson two hit rule for tumour suppressor genes is fulfilled. Alternatively, regions with UPD may contain bi-allelic hypermethylated and thus silenced (candidate tumour suppressor) genes. SNP analysis is a promising approach to genome wide analysis in lymphoma and is now supported by efficient commercially available platforms which are widely available.

The major problem of SNP analysis is the difficulty in distinguishing acquired abnormalities from polymorphisms. This can only be conclusively resolved by analysing paired germ line (for instance derived from a buccal swab) and tumour material from the same patient. ${ }^{36}$ Comparing the data from the individual cancer with large SNP databases of germ line material to correct for all potential polymorphisms is still not reliable and this analysis often results in the exclusion of many regions smaller than $250 \mathrm{~kb}$. Polymorphic regions, can even span several megabases, indicating that such a threshold may be even insufficient. Therefore, at the present time, except for the detection of UPD, SNP analysis on archival materials where germline DNA is not available is not superior to aCGH for the genome wide assessment of structural abnormalities. 
$\mathrm{CGH}, \mathrm{aCGH}$ and SNP analysis all have the intrinsic disadvantage that balanced genetic abnormalities (abnormalities without any gain or loss of DNA), and thus most translocations and inversions are missed (Table 1). Interestingly, due to the fact that many structural abnormalities like chromosomal breakpoints in lymphomas are associated with mutations and also small deletions or duplications of several nucleotides, such abnormalities may in fact be detectable by SNP analysis. However, this potential of SNP analysis has not been systematically addressed so far.

\section{Interphase (and metaphase) fluorescent in situ hybridization}

Interphase fluorescent in situ hybridization (interphase FISH) on cytospin preparations, imprinted fresh cells or paraffin tissue sections or metaphase cells of the tumour (metaphase $\underline{\text { FISH) }}$ ) has become a routine technique in many laboratories. ${ }^{11,12,43-47}$ The technique is mainly used to detect well characterised structural chromosomal abnormalities such as recurrent chromosomal breakpoints or juxtaposition of two different loci involved in chromosomal translocations. The method can also be used to detect amplification or low level gains and losses of loci. However, real amplifications as seen in solid tumours are relatively rare in lymphomas. Moreover, the detection of low copy gains and losses in tissue sections is much more problematic than detection of breakpoints for which sets of probes are available that allow easy "pattern recognition" (see below). ${ }^{48}$ Identification and counting of signals per cell on tissue sections is impeded by many factors like cutting artefacts and nuclear overlap related to the thickness and homogeneity of the tissue sections, the size of the nuclei, as well as the fixation. Thus for a reliable assessment of subtle copy number variations (low levels of gains and losses) FISH on isolated nuclei either prepared from intact cell suspension or nuclear suspensions from paraffin blocks is preferable. ${ }^{49-52}$

For detection of the most common recurrent translocations including those affecting 8q24/MYC, 18q21/BCL2, 3q27/BCL6, 18q21/MALT1 efficient probe sets and protocols for hybridization procedures are now commercially available. These are based on two colour probe sets which generate patterns that allow normal cells to be distinguished from those with a mono-allelic or bi-allelic breakpoint. ${ }^{12,48}$

A good example of the usefulness of interphase FISH is detection of 8q24/MYC breakpoints and exclusion of other breakpoints in Burkitt lymphoma. In $>90 \%$ of all Burkitt lymphomas a $\mathrm{t}(8 ; 14)(\mathrm{q} 24 ; \mathrm{q} 32), \mathrm{t}(2 ; 8)$ or $\mathrm{t}(8 ; 22)$ will be found whereas $\mathrm{t}(14 ; 18)(\mathrm{q} 32 ; \mathrm{q} 21)$ affecting $B C L 2$ 
and 3q27 breakpoints affecting BCL6 should be absent. In contrast in 5-20\% of all diffuse large B-cell lymphoma MYC breakpoints can also be detected, more than half of these cases sharing a $\mathrm{t}(14 ; 18)(\mathrm{q} 32 ; \mathrm{q} 21)$ and / or a $3 \mathrm{q} 27$ breakpoint, thus representing a so called "double hit lymphoma". ${ }^{2}$ The latter lymphomas were previously diagnosed as diffuse large B cell lymphoma, Burkitt-like lymphoma, atypical Burkitt lymphoma or aggressive B cell lymphoma NOS and represent very aggressive lymphomas that behave differently from classical Burkitt lymphoma and are difficult to treat with regimens like R-CHOP or high intensity - short duration polychemotherapy. 53

MYC breakpoints can be detected by FISH in different ways. The most widely used approach is a segregation or split assay using two differently coloured probes that flank the MYC locus at $8 \mathrm{q} 24$. In case of a green and red label, the two probes are seen as a yellow or red/green signal in normal interphase nuclei. In case of a mono-allelic break, the nucleus will show one normal signal derived from the normal 8q24 allele and one split signal with separate green and red signals. It is estimated that more than $90 \%$ of the breakpoints in Burkitt lymphoma are detected by the currently available probe sets. The few failures are partly due to the presence of cryptic rearrangements that can be missed by some assays. ${ }^{43,54}$ In this MYC segregation assay, only a MYC breakpoint is detected and no information is given on the partner that is juxtaposed to $M Y C$. In Burkitt lymphoma the partners are exclusively immunoglobulin loci ( $85 \%$ IGH, $>10 \%$ lambda and $<5 \%$ kappa), so for the diagnosis of Burkitt lymphoma the segregation assay could be replaced by more specific co-localization assays for $M Y C$ with $I G H$, or $M Y C$ with $I G L$ and $M Y C$ with $I G K$. However, in other lymphomas like diffuse large B-cell lymphoma with a MYC breakpoint, IGH/IGK/IGL and $M Y C$ are juxtaposed in only two thirds of the cases. In the other cases loci like a locus at 9p13 or BCL6 at 3q27 are the partners of MYC. Thus, to detect all 8q24/MYC breakpoints in Burkitt lymphoma and diffuse large B-cell lymphoma (and other lymphomas), all cases should always first be assessed by a simple $M Y C$ segregation assay. After this screening, a FISH test for juxtaposition of the $M Y C$ locus to one of the immunoglobulin loci should be applied, since absence of any type of co-localization with the immunoglobulin genes is strong evidence against a diagnosis of Burkitt lymphoma. ${ }^{13}$ Figure 3 shows an example of a MYC-IGH colocalisation FISH pattern in a case of Burkitt lymphoma with a MYC-break.

Because of the diagnostic and therapeutic consequences it is recommended that $8 \mathrm{q} 24 / M Y C$ FISH analysis is carried out on all B cell lymphomas that share some features with Burkitt 
lymphoma, particularly in adult patients. The analysis should include a segregation assay for 8q24/ $M Y C$, and preferably also a co-localization assay for $M Y C$ and the $I G$ loci, as well as a segregation assay for both $B C L 2$ and $B C L 6$ to rule out a double hit lymphoma.

One major drawback of FISH tests is the need to have immunofluorescence microscopy equipment and expertise to analyse the slides in a dark room. It sometimes is difficult to find the optimal regions with most tumour cells in such slides. Several companies are currently preparing bright field in situ hybridization methods (BRISH) making use of chromogenic substances and/or silver that could replace dual colour FISH tests, allowing pathologists to read slides at the normal bright-field microscope and to better correlate the signal pattern with the microscopic anatomy of the tumour. ${ }^{55-57}$ An additional advantage of BRISH over FISH is that the specimen can be archived and that inter-laboratory quality control programs are much easier to perform. However, the major problem of BRISH is the visualization of exactly colocalizing signals.

\section{Polymerase chain reaction (PCR), real time polymerase chain reaction PCR (RT-PCR).} In the diagnosis of lymphoma PCR tests at the DNA level are used mostlyfor clonality analysis of the immunoglobulin genes or T cell receptor genes. Highly sensitive and specific primer combinations and protocols have been developed most notably by the BIOMED consortium (http://www.euroclonality.org/). These tests are currently used worldwide and enable to detect clonality in fresh tissues as well as in archival, FFPE materials. ${ }^{58-61}$

Some translocations, such as the $\mathrm{t}(14 ; 18)$ involving $B C L 2$, can be detected at the genomic level by PCR. However in view of the diversity of breakpoints multiple tube tests with many sets of different primers are necessary to detect most $\mathrm{t}(14 ; 18)$ breakpoints. ${ }^{61}$ This problem in detecting chromosomal breakpoints is even more evident for the $\mathrm{t}(11 ; 14)(\mathrm{q} 13 ; \mathrm{q} 32)$ in mantle cell lymphoma. Extensive mapping studies have shown that only $30-40 \%$ of all $\mathrm{t}(11 ; 14)$ breakpoints cluster in a small region (MTC) in which the breakpoint can be detected by PCR. ${ }^{62}{ }^{63}$ Since FISH probes that cover all breakpoints can be easily designed, this technique is superior. Another disadvantage of PCR is that this method in general makes use of primers that flank the breakpoint, and therefore the primers have to be derived from both partners. In consequence both partners should be consistently involved, otherwise breakpoints will be missed. 
On the other hand, if a breakpoint is amplifiable by PCR, it is a far superior method for the detection and quantification of small numbers of cells, and thus in the detection of minimal residual disease (MRD). PCR has been used to detect MRD after intensive chemotherapy and stem cell transplant in patients with mantle cell lymphoma with an amplifiable $t(11 ; 14)$ breakpoint. $^{64}$

Quantitative RT-PCR is very useful for the detection of chromosomal translocations that lead to the production of novel fusion mRNA transcripts. Such events form the minority of translocations in lymphomas (but the majority in myeloid neoplasms), since most translocations are derived from RAG1/2 or AICDA mediated juxtaposition of oncogenes to the enhancers of immunoglobulin gene or $\mathrm{T}$ cell receptor genes, leaving the protein-encoding domains intact. Examples of translocation that generate fusion transcripts and proteins are those involving ALK1 in ALK+ anaplastic large cell lymphomas (ALK+ ALCL) and ALK+ large B cell lymphoma (ALK+ DLBCL). In the great majority $A L K$ and $N P M$ are fused giving rise to a fusion protein with nuclear and cytoplasmic localization. In addition in $5-30 \%$ of the gastric and in 30-50\% of pulmonary marginal zone B cell (MALT) lymphomas, a $\mathrm{t}(11 ; 18)(\mathrm{q} 21 ; 21)$ with fusion of $A P I 2$ and MALT1 is present. In gastric lymphomas the presence of this translocation is associated with resistance to Helicobacter pylori eradication therapy. Because of the therapeutic consequences it is recommended to either FISH or RTPCR to detect this translocation routinely in marginal zone lymphomas. ${ }^{65}$

The better performance of RT-PCR on cDNA than PCR on DNA in the detection of translocations is because the number of exons involved in the breakpoints is limited and RNA splicing eliminates long stretches of (intronic) nucleotides that can not be efficiently amplified by PCR on DNA. In consequence, most fusion breakpoints can be detected by RTPCR with a very limited number of primer combinations. Also because of these characteristics, RT-PCR can be used on FFPE material. Formalin fixation has the advantage that endonucleases that degrade RNA are rapidly inactivated. On the other hand, apart from cross-linking and fragmentation of RNA, formalin also induces the addition of monoethylol groups to adenosine and consequently inhibits primer annealing for reverse transcription. Specific protocols are now for optimal RNA extraction and efficient cDNA synthesis from FFPE material. 
Despite all optimized procedures, the efficiency of RT-PCR using RNA extracted from FFPE material remains approximately 30-50-fold lower than RNA extracted from matched frozen materials. This topic has been extensively reviewed by Farragher et al and the reader should consult these sources for more detailed information on the protocols that are now available ${ }^{66-}$ 69

\section{Other molecular methods.}

Several other molecular methods can be used for quantification of DNA targets and thus for the detection of copy number variations. They include quantitative fluorescent PCR of short tandem repeats (QF-PCR of STR), multiplex PCR of short exonic sequences (QMPSF) and multiplex ligation probe amplification (MLPA). ${ }^{70}$ In principle all techniques enable to assay multiple loci for gains or losses, and therefore they could be helpful in the assessment of the genomic complexity, for instance as a tool to differentiate between Burkitt lymphoma and diffuse large B cell lymphoma. As far as known, none of these techniques have been introduced yet into a diagnostic haematopathology setting. Moreover, like for CGH methods and SNP analysis, these methods do not allow detecting reciprocal translocations.

\section{$\underline{\text { 8. Immunohistochemisty and molecular cytogenetics. }}$}

This review would not be complete without a comment on the use immunohistochemistry for the detection of genetic abnormlaties. In fact immunohistochemistry may in some instances replace molecular cytogenetics. ${ }^{73}$ Chromosomal abnormalities cause deregulation of genes that are not expressed in normal B cells or T cells, or are not expressed in a specific stage of maturation of normal B or T cells. An example is the $\mathrm{t}(11 ; 14)(\mathrm{q} 13 ; \mathrm{q} 32)$ present in $>95 \%$ of all mantle cell lymphomas. This translocation gives rise to activation of CCND1 by juxtaposing to an immunoglobulin gene enhancer, and in consequence CCND1 expression is induced while it is not expressed in normal B and T cells. Previous work has shown that there is an excellent correlation between the presence of a translocation and expression of CCND1 at the RNA and protein level (western blot and immunohistochemistry). ${ }^{63,74}$ Excellent monoclonal antibodies against CCND1 have been developed and in consequence immunohistochemistry for CCND1 has almost completely replaced the molecular methods to detect this translocation. ${ }^{75}$ 
A second example is the detection of $A L K$ translocations in ALK+ anaplastic large cell lymphoma (ALCL) and ALK+ diffuse large B cell lymphoma. These lymphomas and also a subset of inflammatory myofibroblastic tumours contain a fusion of the $A L K$ gene at $2 \mathrm{p} 23$ to a large variety of other partners (NPM being the most frequent partner). Since ALK is not expressed in normal adult tissues, ALK expression in these tumours as observed by immunohistochemistry shows that a fusion protein containing ALK is present (table 2). In all lymphomas and inflammatory myofibroblastic tumours with an $A L K$ breakpoint this expression is high and can be easily detected by immunohistochemistry. In consequence, immunohistochemistry has completely replaced molecular methods. Notably, the pattern of its expression within the cells as seen in tissue slides informs us also on the $A L K$ fusion partner used in the translocation. ${ }^{76}$ Recent research has shown that $A L K$ inversions involving the EML4 gene occur in approximately 4-9\% of all adenocarcinomas of the lung. However, in these cases a very low level of ALK protein expression is present that only can be detected using specific antibodies and very sensitive assays. ${ }^{77}$

A third example is the use of antibodies against SOX11 in the diagnosis of mantle cell lymphoma. SOX11 encodes a member of the SOX (SRY-related HMG-box) family of transcription factors involved in the regulation of embryonic development. Based on gene expression studies this gene appeared to be highly expressed in almost all mantle cell lymphomas in addition to some acute lymphoblastic lymphomas / leukaemias, Burkitt lymphomas and hairy cell leukaemias. Interestingly, $t(11 ; 14)$ and CCND1 protein negative mantle cell lymphomas are SOX11 positive. ${ }^{78-80}$ Other publications suggest that very indolent but also rare very aggressive mantle cell lymphomas may be negative for SOX11. ${ }^{81,82}$

\section{Molecular cytogenetic aspects of individual lymphomas}

In Table 2, a brief summary is given of the most common molecular abnormalities in specific lymphomas, ${ }^{1}$ the methods to detect these abnormalities, as well as their diagnostic and clinical relevance. Excellent web resources include (http://atlasgeneticsoncology.org/, http://www.progenetix.net/ and

http://www.ncbi.nlm.nih.gov/sites/entrez?db=cancerchromosomes) and elsewhere. ${ }^{4,11}$

\section{Conclusions and future perspectives}


Molecular genetics has now become an integral part of routine lymphoma diagnostics. In many laboratories, PCR based clonality tests and FISH investigations for specific chromosomal abnormalities are performed on a routine basis. One challenge for the future will be to develop multicolour BRISH instead of fluorescent in situ hybridization (FISH) assays for detection of all breakpoints and relevant numerical abnormalities in lymphomas. The introduction of reliable BRISH assays will allow many more pathologists to perform and interpret these tests.

High throughput methods such array CGH, SNP analysis and whole genome expression analysis have not been introduced into routine diagnostic laboratories. This may be facilitated in the near future by providing tailor made platforms with a limited number of targets to be detected. There is clearly a place for such assays, for instance for the differential diagnosis between Burkitt lymphoma and diffuse large B cell lymphoma. Similar approaches could likely be followed to distinguish indolent from conventional mantle cell lymphomas, since there are indications that indolent mantle cell lymphomas have a relatively simple karyotype. $^{82}$ At present, these assays require fresh or freshly frozen material and the question whether these methods will become part of our routine diagnostics is very much dependent on the question whether these techniques will be applicable in routinely FFPE materials.

Finally, it is obvious that the development of new drugs that target specific intracellular or intercellular pathways in specific types of lymphoma, will drive the development of new molecular tests in malignant lymphoma. One example will be new drugs that interfere with specific signalling pathways used in ABC type diffuse large B-cell lymphoma but not GC type. $^{83}$ This will require better methods to distinguish these types of diffuse large B-cell lymphoma, and the detection of the specific molecular abnormalities in the pathway targeted by the drug. Developments of this type are already taking place in other types of tumour. 
Reference List

1. WHO Classification of Tumours of Haematopoietic and Lymphoid Tissues. 4th ed. Lyon: International Agency for Research on Cancer; 2008.

2. Nowell PC, Hungerford DA. Chromosome studies on normal and leukemic human leukocytes. J. Natl. Canc. Inst. 1960 Jul;25:85-109.

3. Jacobs PA, Tough IM, Wright DH. Cytogenetic studies in Burkitt's lymphoma. Lancet 1963 Nov 30;2(7318):1144-1146.

4. Siebert R. Mature B- and T-cell Neoplasms and Hodgkin Lymphoma. In Heim S, Mitelman F, eds. Cancer Cytogenetics. third ed. Wiley-Blackwell; 2009. 297-374.

5. Barrans S, Crouch S, Smith A, et al. Rearrangement of MYC is associated with poor prognosis in patients with diffuse large B-cell lymphoma treated in the era of rituximab. J. Clin. Oncol. 2010 Jul 10;28(20):3360-3365.

6. Carbone A, Gloghini A, Aiello A, Testi A, Cabras A. B-cell lymphomas with features intermediate between distinct pathologic entities. From pathogenesis to pathology. Hum. Pathol. 2010 May;41(5):621-631.

7. Johnson NA, Savage KJ, Ludkovski O, et al. Lymphomas with concurrent BCL2 and MYC translocations: the critical factors associated with survival. Blood 2009 Sep 10;114(11):2273-2279.

8. Hasserjian RP, Ott G, Elenitoba-Johnson KS, Balague-Ponz O, De Jong D, de Leval L. Commentary on the WHO classification of tumors of lymphoid tissues (2008): "Gray zone" lymphomas overlapping with Burkitt lymphoma or classical Hodgkin lymphoma. J. Hematop. 2009 Jun 27.

9. Tomita N, Tokunaka M, Nakamura N, et al. Clinicopathological features of lymphoma/leukemia patients carrying both BCL2 and MYC translocations. Haematologica 2009 Jul;94(7):935-943.

10. Le Gouill S, Talmant $\mathrm{P}$, Touzeau $\mathrm{C}$, et al. The clinical presentation and prognosis of diffuse large B-cell lymphoma with $\mathrm{t}(14 ; 18)$ and 8q24/c-MYC rearrangement. Haematologica 2007 Oct;92(10):1335-1342.

11. Ventura RA, Martin-Subero JI, Jones M, et al. FISH analysis for the detection of lymphoma-associated chromosomal abnormalities in routine paraffin-embedded tissue. J. Mol. Diagn. 2006 May;8(2):141-151.

12. Haralambieva E, Kleiverda K, Mason DY, Schuuring E, Kluin PM. Detection of three common translocation breakpoints in non-Hodgkin's lymphomas by fluorescence in situ hybridization on routine paraffin-embedded tissue sections. J. Pathol. 2002 Oct;198(2):163-170. 
13. Boerma EG, Siebert R, Kluin PM, Baudis M. Translocations involving 8q24 in Burkitt lymphoma and other malignant lymphomas: a historical review of cytogenetics in the light of todays knowledge. Leukemia 2009;23(2):225-234.

14. Toujani S, Dessen $\mathrm{P}$, Ithzar N, et al. High resolution genome-wide analysis of chromosomal alterations in Burkitt's lymphoma. PLoS. One. 2009;4(9):e7089.

15. Hummel $\mathrm{M}$, Bentink $\mathrm{S}$, Berger $\mathrm{H}$, et al. A biologic definition of Burkitt's lymphoma from transcriptional and genomic profiling. N. Engl. J. Med. 2006 Jun $8 ; 354(23): 2419-2430$.

16. Seegmiller AC, Garcia R, Huang R, Maleki A, Karandikar NJ, Chen W. Simple karyotype and bcl-6 expression predict a diagnosis of Burkitt lymphoma and better survival in IG-MYC rearranged high-grade B-cell lymphomas. Mod. Pathol. 2010 Jul;23(7):909-920.

17. Salaverria I, Zettl A, Bea S, et al. Chromosomal alterations detected by comparative genomic hybridization in subgroups of gene expression-defined Burkitt's lymphoma. Haematologica 2008 Sep;93(9):1327-1334.

18. Chesi M, Bergsagel PL, Brents LA, Smith CM, Gerhard DS, Kuehl WM. Dysregulation of cyclin D1 by translocation into IgH gamma switch region in two multiple myeloma cell lines. Blood 1996;88:674-681.

19. Janssen JWG, Vaandrager JW, Heuser T, et al. Concurrent activation of a novel putative transforming gene, MYEOV, and cyclin D1 i a subset of multiple myeloma cell lines with $\mathrm{t}(11 ; 14)(\mathrm{q} 13 ; \mathrm{q} 32)$. Blood 2000;95(8):2691-2698.

20. Speicher MR, Gwyn Ballard S, Ward DC. Karyotyping human chromosomes by combinatorial multi-fluor FISH. Nat. Genet. 1996 Apr;12(4):368-375.

21. Tanke HJ, Wiegant J, van Gijlswijk RP, et al. New strategy for multi-colour fluorescence in situ hybridisation: COBRA: COmbined Binary RAtio labelling. Eur. J. Hum. Genet. 1999 Jan;7(1):2-11.

22. Gisselsson D. Refined characterisation of chromosome aberrations in tumours by multicolour banding and electronic mapping resources. Methods Cell Sci. 2001;23(13):23-28.

23. Veldman T, Vignon C, Schröck E, Rowley JD, Ried T. Hidden chromosome abnormalities in haematological malignancies detected by multicolour spectral karyotyping. Nature Genetics 1997;15:406-410.

24. Kearney L. Multiplex-FISH (M-FISH): technique, developments and applications. Cytogenet. Genome Res. 2006;114(3-4):189-198.

25. Lichter P, Joos S, Bentz M, Lampel S. Comparative genomic hybridization: uses and limitations. Semin. Hematol. 2000 Oct;37(4):348-357.

26. Bentz M, Dohner H, Werner CA, et al. Identification of genetic imbalances in malignant lymphoma using comparative genomic hybridization. Stem Cells 1995 Dec;13 Suppl 3:83-87. 
27. Salaverria I, Bea S, Lopez-Guillermo A, et al. Genomic profiling reveals different genetic aberrations in systemic ALK-positive and ALK-negative anaplastic large cell lymphomas. Br. J. Haematol. 2008 Mar;140(5):516-526.

28. Seto M, Honma K, Nakagawa M. Diversity of genome profiles in malignant lymphoma. Cancer Sci. 2010 Mar;101(3):573-578.

29. Takeuchi I, Tagawa H, Tsujikawa A, et al. The potential of copy number gains and losses, detected by array-based comparative genomic hybridization, for computational differential diagnosis of B-cell lymphomas and genetic regions involved in lymphomagenesis. Haematologica 2009 Jan;94(1):61-69.

30. Booman M, Szuhai K, Rosenwald A, et al. Genomic alterations and gene expression in primary diffuse large B-cell lymphomas of immune-privileged sites: the importance of apoptosis and immunomodulatory pathways. J. Pathol. 2008 Oct;216(2):209-217.

31. Schraders M, Jares P, Bea S, et al. Integrated genomic and expression profiling in mantle cell lymphoma: identification of gene-dosage regulated candidate genes. $\mathrm{Br}$. J. Haematol. 2008 Oct;143(2):210-221.

32. Wessendorf S, Barth TF, Viardot A, et al. Further delineation of chromosomal consensus regions in primary mediastinal B-cell lymphomas: an analysis of 37 tumor samples using high-resolution genomic profiling (array-CGH). Leukemia 2007 Dec;21(12):2463-2469.

33. Thorns C, Bastian B, Pinkel D, et al. Chromosomal aberrations in angioimmunoblastic T-cell lymphoma and peripheral T-cell lymphoma unspecified: A matrix-based CGH approach. Genes Chromosomes. Cancer 2007 Jan;46(1):37-44.

34. de Leeuw RJ, Davies JJ, Rosenwald A, et al. Comprehensive whole genome array CGH profiling of mantle cell lymphoma model genomes. Hum. Mol. Genet. 2004 Sep 1;13(17):1827-1837.

35. Lenz G, Wright GW, Emre NC, et al. Molecular subtypes of diffuse large B-cell lymphoma arise by distinct genetic pathways. Proc. Natl. Acad. Sci. U. S. A 2008 Sep 9;105(36):13520-13525.

36. Heinrichs S, Li C, Look AT. SNP array analysis in hematologic malignancies: avoiding false discoveries. Blood 2010 May 27;115(21):4157-4161.

37. Wang Y, Armstrong SA. Genome-wide SNP analysis in cancer: leukemia shows the way. Cancer Cell 2007 Apr;11(4):308-309.

38. Bea S, Salaverria I, Armengol L, et al. Uniparental disomies, homozygous deletions, amplifications, and target genes in mantle cell lymphoma revealed by integrative highresolution whole-genome profiling. Blood 2009 Mar 26;113(13):3059-3069.

39. Schwindt H, Vater I, Kreuz M, et al. Chromosomal imbalances and partial uniparental disomies in primary central nervous system lymphoma. Leukemia 2009

Oct;23(10):1875-1884. 
40. O'Shea D, O'Riain C, Gupta M, et al. Regions of acquired uniparental disomy at diagnosis of follicular lymphoma are associated with both overall survival and risk of transformation. Blood 2009 Mar 5;113(10):2298-2301.

41. Fitzgibbon J, Iqbal S, Davies A, et al. Genome-wide detection of recurring sites of uniparental disomy in follicular and transformed follicular lymphoma. Leukemia 2007 Jul;21(7):1514-1520.

42. Nielaender I, Martin-Subero JI, Wagner F, Martinez-Climent JA, Siebert R. Partial uniparental disomy: a recurrent genetic mechanism alternative to chromosomal deletion in malignant lymphoma. Leukemia 2006 May;20(5):904-905.

43. Haralambieva E, Schuuring E, Rosati S, et al. Interphase fluorescence in situ hybridization for detection of 8q24/MYC breakpoints on routine histologic sections: Validation in Burkitt lymphomas from three geographic regions. Genes Chromosomes \& Cancer 2004 May;40(1):10-18.

44. Martin-Subero JI, Gesk S, Harder L, Grote W, Siebert R. Interphase cytogenetics of hematological neoplasms under the perspective of the novel WHO classification. Anticancer Res. 2003 Mar;23(2A):1139-1148.

45. Wolff DJ, Bagg A, Cooley LD, et al. Guidance for fluorescence in situ hybridization testing in hematologic disorders. J. Mol. Diagn. 2007 Apr;9(2):134-143.

46. Barrans SL, Evans PA, O'Connor SJ, Owen RG, Morgan GJ, Jack AS. The detection of $\mathrm{t}(14 ; 18)$ in archival lymph nodes: development of a fluorescence in situ hybridization (FISH)-based method and evaluation by comparison with polymerase chain reaction. J. Mol. Diagn. 2003 Aug;5(3):168-175.

47. Vaandrager JW, Schuuring E, Raap T, Philippo K, Kleiverda K, Kluin P. Interphase FISH detection of BCL2 rearrangement in follicular lymphoma using breakpointflanking probes. Genes Chromosomes \& Cancer 2000 Jan;27(1):85-94.

48. Haralambieva E, Banham AH, Bastard C, et al. Detection by the fluorescence in situ hybridization technique of MYC translocations in paraffin-embedded lymphoma biopsy samples. Br. J. Haematol. 2003 Apr;121(1):49-56.

49. Thompson CT, Gray JW. Cytogenetic profiling using fluorescence in situ hybridization (FISH) and comparative genomic hybridization (CGH). J. Cell Biochem. Suppl 1993;17G:139-143.

50. Qian J, Bostwick DG, Takahashi S, et al. Comparison of fluorescence in situ hybridization analysis of isolated nuclei and routine histological sections from paraffin-embedded prostatic adenocarcinoma specimens. Am. J. Pathol. 1996 Oct;149(4):1193-1199.

51. Jordanova ES, Corver WE, Vonk MJ, et al. Flow cytometric sorting of paraffinembedded tumor tissues considerably improves molecular genetic analysis. American Journal of Clinical Pathology 2003 Sep;120(3):327-334.

52. Jordanova ES, Riemersma SA, Philippo K, Giphart-Gassler M, Schuuring E, Kluin PM. Hemizygous deletions in the HLA region account for loss of heterozygosity in the 
majority of diffuse large B-cell lymphomas of the testis and the central nervous system. Genes Chromosomes \& Cancer 2002 Sep;35(1):38-48.

53. Mead GM, Barrans SL, Qian W, et al. A prospective clinicopathologic study of dosemodified CODOX-M/IVAC in patients with sporadic Burkitt lymphoma defined using cytogenetic and immunophenotypic criteria (MRC/NCRI LY10 trial). Blood 2008 Sep 15;112(6):2248-2260.

54. May PC, Foot N, Dunn R, Geoghegan H, Neat MJ. Detection of cryptic and variant IGH-MYC rearrangements in high-grade non-Hodgkin's lymphoma by fluorescence in situ hybridization: implications for cytogenetic testing. Cancer Genet. Cytogenet. 2010 Apr 1;198(1):71-75.

55. Nitta H, Zhang W, Kelly BD, et al. Automated brightfield break-apart in situ hybridization (ba-ISH) application: ALK and MALT1 genes as models. Methods 2010 Jul 16.

56. Stasik CJ, Nitta H, Zhang W, et al. Increased MYC gene copy number correlates with increased mRNA levels in diffuse large B-cell lymphoma. Haematologica 2010 Apr;95(4):597-603.

57. van Rijk A, Svenstroup-Poulsen T, Jones M, et al. Double-staining chromogenic in situ hybridization as a useful alternative to split-signal fluorescence in situ hybridization in lymphoma diagnostics. Haematologica 2010 Feb;95(2):247-252.

58. van Krieken JH, Langerak AW, Macintyre EA, et al. Improved reliability of lymphoma diagnostics via PCR-based clonality testing: report of the BIOMED-2 Concerted Action BHM4-CT98-3936. Leukemia 2007 Feb;21(2):201-206.

59. Langerak AW, Molina TJ, Lavender FL, et al. Polymerase chain reaction-based clonality testing in tissue samples with reactive lymphoproliferations: usefulness and pitfalls. A report of the BIOMED-2 Concerted Action BMH4-CT98-3936. Leukemia $2007 \mathrm{Feb} ; 21(2): 222-229$.

60. Sandberg Y, Gastel-Mol EJ, Verhaaf B, Lam KH, van Dongen JJ, Langerak AW. BIOMED-2 multiplex immunoglobulin/T-cell receptor polymerase chain reaction protocols can reliably replace Southern blot analysis in routine clonality diagnostics. $J$. Mol. Diagn. 2005 Oct;7(4):495-503.

61. van Dongen JJ, Langerak AW, Bruggemann M, et al. Design and standardization of PCR primers and protocols for detection of clonal immunoglobulin and T-cell receptor gene recombinations in suspect lymphoproliferations: report of the BIOMED-2 Concerted Action BMH4-CT98-3936. Leukemia 2003 Dec;17(12):2257-2317.

62. Vaandrager JW, Schuuring E, Zwikstra E, et al. Direct visualization of dispersed 11 13 chromosomal translocations in mantle cell lymphoma by multicolor DNA fiber fluorescence in situ hybridization. Blood 1996 Aug 15;88(4):1177-1182.

63. De Boer CJ, Van Krieken JHJM, Schuuring E, Kluin PM. BCL1/cyclin D1 in malignant lymphoma. Ann. Oncol. 1997;8 (suppl 2):109-117. 
64. Andersen NS, Pedersen LB, Laurell A, et al. Pre-emptive treatment with rituximab of molecular relapse after autologous stem cell transplantation in mantle cell lymphoma. J. Clin. Oncol. 2009 Sep 10;27(26):4365-4370.

65. Liu H, Ye H, Ruskone-Fourmestraux A, et al. $\mathrm{T}(11 ; 18)$ is a marker for all stage gastric MALT lymphomas that will not respond to $\mathrm{H}$. pylori eradication

3. Gastroenterology 2002 May;122(5):1286-1294.

66. Farragher SM, Tanney A, Kennedy RD, Paul Harkin D. RNA expression analysis from formalin fixed paraffin embedded tissues. Histochem. Cell Biol. 2008 Sep;130(3):435-445.

67. Specht K, Richter T, Muller U, Walch A, Werner M, Hofler H. Quantitative gene expression analysis in microdissected archival formalin-fixed and paraffin-embedded tumor tissue. Am. J. Pathol. 2001 Feb;158(2):419-429.

68. Green TM, de Stricker K, Moller MB. Validation of putative reference genes for normalization of Q-RT-PCR data from paraffin-embedded lymphoid tissue.

Diagnostic Molecular Pathology 2009 Dec;18(4):243-249.

69. van Maldegem F, de Wit M, Morsink F, Musler A, Weegenaar J, van Noesel CJ. Effects of processing delay, formalin fixation, and immunohistochemistry on RNA Recovery From Formalin-fixed Paraffin-embedded Tissue Sections. Diagnostic Molecular Pathology 2008 Mar;17(1):51-58.

70. Gouas L, Goumy C, Veronese L, Tchirkov A, Vago P. Gene dosage methods as diagnostic tools for the identification of chromosome abnormalities. Pathol. Biol. (Paris) 2008 Sep;56(6):345-353.

71. Alizadeh AA, Eisen MB, Davis RE, et al. Distinct types of diffuse large B-cell lymphoma identified by gene expression profiling. Nature 2000 Feb 3;403(6769):503511.

72. Hartmann EM, Ott G, Rosenwald A. Molecular biology and genetics of lymphomas. Hematol. Oncol. Clin. North Am. 2008 Oct;22(5):807-23, vii.

73. Falini B, Mason DY. Proteins encoded by genes involved in chromosomal alterations in lymphoma and leukemia: clinical value of their detection by immunocytochemistry (vol 99, pg 409, 2002)

88. Blood 2002 Feb 15;99(4):1108.

74. De Boer CJ, Schuuring E, Dreef EJ, et al. Cyclin D1 protein analysis in the diagnosis of mantle cell lymphoma. Blood 1995;86:2715-2723.

75. Cheuk W, Wong KO, Wong CS, Chan JK. Consistent immunostaining for cyclin D1 can be achieved on a routine basis using a newly available rabbit monoclonal antibody. Am. J. Surg. Pathol. 2004 Jun;28(6):801-807.

76. Stein H, Foss HD, Durkop H, et al. CD30(+) anaplastic large cell lymphoma: a review of its histopathologic, genetic, and clinical features

140. Blood 2000 Dec 1;96(12):3681-3695. 
77. Mino-Kenudson M, Chirieac LR, Law K, et al. A novel, highly sensitive antibody allows for the routine detection of ALK-rearranged lung adenocarcinomas by standard immunohistochemistry. Clin. Cancer Res. 2010 Mar 1;16(5):1561-1571.

78. Ek S, Dictor M, Jerkeman M, Jirstrom K, Borrebaeck CA. Nuclear expression of the non B-cell lineage Sox 11 transcription factor identifies mantle cell lymphoma. Blood 2008 Jan 15;111(2):800-805.

79. Mozos A, Royo C, Hartmann E, et al. SOX11 expression is highly specific for mantle cell lymphoma and identifies the cyclin D1-negative subtype. Haematologica 2009 Nov;94(11):1555-1562.

80. Chen YH, Gao J, Fan G, Peterson LC. Nuclear expression of sox11 is highly associated with mantle cell lymphoma but is independent of $\mathrm{t}(11 ; 14)(\mathrm{q} 13 ; \mathrm{q} 32)$ in nonmantle cell B-cell neoplasms. Mod. Pathol. 2010 Jan;23(1):105-112.

81. Wang X, Asplund AC, Porwit A, et al. The subcellular Sox 11 distribution pattern identifies subsets of mantle cell lymphoma: correlation to overall survival. $B r . J$. Haematol. 2008 Oct;143(2):248-252.

82. Fernandez V, Salamero O, Espinet B, et al. Genomic and gene expression profiling defines indolent forms of mantle cell lymphoma. Cancer Res. $2010 \mathrm{Feb}$ 15;70(4):1408-1418.

83. Hailfinger S, Lenz G, Ngo V, et al. Essential role of MALT1 protease activity in activated B cell-like diffuse large B-cell lymphoma. Proc. Natl. Acad. Sci. U. S. A 2009 Nov 24;106(47):19946-19951. 


\section{Legends to the Figures}

\section{Figure 1. Principles of conventional CGH and array CGH.}

Normal DNA and tumor DNA are differentially labeled, often with Cy3 and Cy5. After blocking of (ubiquitously present and thus hindering) repetitive DNA, these labeled DNAs are competitively hybridized to either normal chromosome preparations or a high density array of (preferably) overlapping probes on a glass slide. In case of conventional CGH, the preparations can be directly analyzed on a fluorescence microscope, in cases of an array, dedicated hardware (a microarray scanner) and software is necessary.

\section{Figure 2. Array CGH analysis and SNP analysis of pediatric Burkitt lymphoma.}

Panel A shows conventional CGH analysis of a series of 15 paediatric Burkitt lymphomas is show. Each black bar to the right of a chromosome represents gain in an individual case; each grey bar to the left side of a chromosome represents loss. This analysis shows a limited number of recurrent aberrations, such as copy number increase of chromosome 13q31-32 and loss of chromosome $17 \mathrm{p}$.

Panel B shows a SNP analysis of 18 paediatric Burkitt lymphomas is shown. The human CNV370-DUO BeadChips (Illumina Inc, San Diego, CA, USA) array was used. SNP array data were imported into BeadStudio (Illumina Inc, San Diego, CA, USA) and analyzed using the Chromozone bookmark plug-in and a modified version of SOMATICs. Directly to the right of each chromosome, the black bar indicates the region that is covered by the probes. Gains are indicated by green bars richt of the chromosomes, losses by red bars (left of the chromosome). Note the higher resolution but also the higher complexity, with in particular a larger number of smaller events, in particular around the centromeres of chromosomes. A large number of these alterations reflect copy number variations between individuals and are not tumour specific.

Panel C shows a case analyzed by SNP's with a small homozygous deletion on 9p21, containing only the CDKNBA and CDKN2B genes. In a second case (not shown) there was a large hemizygous deletion and a similar small deletion on the other allele. These small deletions were not detected by either conventional CGH or array CGH (data not shown). 


\section{Figure 3. Colocalization of MYC and IGH in Burkitt lymphoma.}

A case of paediatric Burkitt lymphoma with presentation in the tonsil with a MYC-break (detected with the Vysis LSI MYC Dual Color, Break Apart Rearrangement Probe set from Abbott molecular; data not shown), was hybridized with the Vysis LSI IGH/MYC, CEP 8 Tricolor, Dual Fusion Translocation Probe. Many cells show fusion of the MYC (green) and IGH (red) signals (arrows). Note that the percentage of spurious co-localizing signals can be high in normal cells, up to $20 \%$ of all cells. 
TABLE 1. INTRINSIC FEATURES OF MOLECULAR GENETIC METHODS

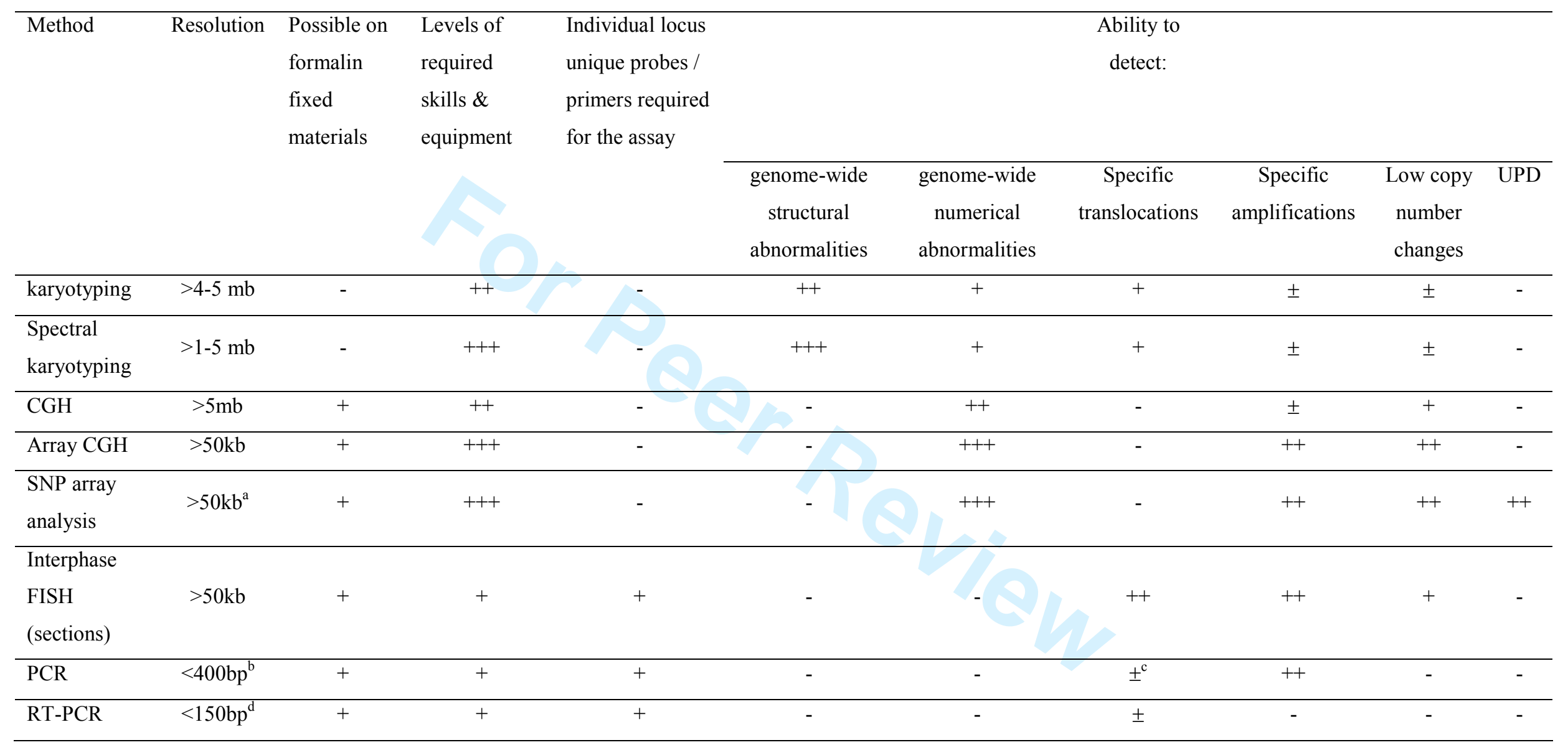

UPD: uniparental disomy; CGH: comparative genomic hybridization; SNP: single nucleotide polymorphism; FISH: fluorescence in situ hybridization; PCR: polymerase chain reaction; RT-PCR: reverse transcription PCR. ${ }^{a}$ : Theoretically very high resolution, practically limited by polymorphisms. ${ }^{b}:<400$ bp in formalin fixed materials. ${ }^{c}:$ very much dependent on the individual translocations, see text. ${ }^{\mathrm{d}}$ : in formalin fixed materials; only for fusion genes, see text 
TABLE 2. INVENTORY OF MOST COMMON GENETIC ABNORMALITIES AND THEIR DIAGNOSTIC AND CLINICAL SIGNIFICANCE IN PERIPHERAL B- AND T CELL LYMPHOMAS*

\begin{tabular}{|c|c|c|c|c|c|c|}
\hline Lymphoma & Primary event & frequency & Preferable method & comments & & \\
\hline \multicolumn{7}{|c|}{ B cell lymphomas } \\
\hline \multirow[t]{7}{*}{$\begin{array}{l}\text { Mantle cell } \\
\text { lymphoma }\end{array}$} & $\begin{array}{l}\mathrm{t}(11 ; 14)(\mathrm{q} 13 ; \mathrm{q} 32), C C N D 1 \& \\
I G H\end{array}$ & $>95 \%$ & $\begin{array}{l}\text { Immunohistochemistry } \\
\text { (CCND1); FISH; } \\
\text { karyotyping }\end{array}$ & $\begin{array}{l}\text { Except for the major } \\
\text { translocation cluster, } \\
\text { breakpoints at } 11 \mathrm{q} 13 \\
\text { are scattered over } \\
\text { large region, PCR not } \\
\text { useful }\end{array}$ & $\begin{array}{l}\mathrm{t}(11 ; 14) \text { is absent } \\
\text { in extremely rare } \\
\text { cases; diagnosis } \\
\text { can only be made } \\
\text { if all other features } \\
\text { are consistent with } \\
\text { MCL. }\end{array}$ & $\begin{array}{l}\text { Cases with simple } \\
\text { karyotype and only } \\
\text { the } t(11 ; 14) \text { may } \\
\text { have favourable } \\
\text { prognosis }\end{array}$ \\
\hline & Del 13q14,? & $40-50 \%$ & $\begin{array}{l}\text { FISH; karyotyping; } \\
\text { aCGH }\end{array}$ & & & \\
\hline & Del 7p13, TP53 & $20-45 \%$ & $\begin{array}{l}\text { FISH; karyotyping; } \\
\text { aCGH }\end{array}$ & $\begin{array}{l}\text { Associated with } \\
\text { prolymphocytic } \\
\text { morphology? }\end{array}$ & & \\
\hline & Del 11q23, ATM & $20-60 \%$ & $\begin{array}{l}\text { aCGH; FISH, } \\
\text { karyotyping }\end{array}$ & $\begin{array}{l}\text { ATM mutations in } 40- \\
75 \%\end{array}$ & & \\
\hline & Del 9p21, CDKN2A/INK4a & $20-30 \%$ & $\begin{array}{l}\text { FISH; karyotyping; } \\
\text { aCGH }\end{array}$ & $\begin{array}{l}\text { Often small } \\
\text { homozygous deletions }\end{array}$ & & \\
\hline & tetraploidy & $\begin{array}{l}\text { In } 80 \% \text { of } \\
\text { pleomorphic and } \\
35 \% \text { of blastoid } \\
\text { variants }\end{array}$ & karyotyping; aCGH & $\begin{array}{l}\text { Associated with poor } \\
\text { prognosis }\end{array}$ & & \\
\hline & $+8 \mathrm{q} 24$ and $\mathrm{t}(8)(\mathrm{q} 24), M Y C$ & $\begin{array}{l}15-35 \% ; 8 q 24 \\
\text { break in } 5-10 \%\end{array}$ & FISH; karyotyping & $\begin{array}{l}\text { Blastoid morphology, } \\
\text { high Ki67, aggressive } \\
\text { course }\end{array}$ & & \\
\hline
\end{tabular}




\begin{tabular}{|c|c|c|c|c|c|c|}
\hline $\begin{array}{l}\text { Follicular } \\
\text { lymphoma }\end{array}$ & $\mathrm{t}(14 ; 18)(\mathrm{q} 32 ; \mathrm{q} 21) B C L 2 \& I G H$ & $\begin{array}{l}\text { Grade 1/2: } 90 \% \\
\text { Grade 3a: ? } \\
\text { Grade } 3 b: 30 \% \text { or } \\
\text { lower }\end{array}$ & $\begin{array}{l}\text { Immunohistochemistry } \\
\text { (BCL2); FISH; } \\
\text { karyotyping }\end{array}$ & $\begin{array}{l}\text { Most breakpoints can } \\
\text { be detected by } \\
\text { multiple tube PCR }\end{array}$ & & \\
\hline $\begin{array}{r}\text { Diffuse follicle } \\
\text { centre cell } \\
\text { lymphoma }\end{array}$ & $\mathrm{t}(14 ; 18)(\mathrm{q} 32 ; \mathrm{q} 21) B C L 2 \& I G H$ & $100 \%(?)$ & FISH; karyotyping & $\begin{array}{l}\text { According to the } \\
\text { WHO classification } \\
\text { this diagnosis can } \\
\text { only be made after } \\
\text { demonstration of the } \\
\mathrm{t}(14 ; 18)\end{array}$ & $\begin{array}{l}\text { However, some } \\
\text { publications } \\
\text { describe similar } \\
\text { lymphomas } \\
\text { without the } \\
\text { translocation. }\end{array}$ & \\
\hline Burkitt lymphoma & $\begin{array}{l}\mathrm{t}(8 ; 14)(\mathrm{q} 24 ; \mathrm{q} 32), M Y C \& I G H \\
\mathrm{t}(8 ; 22)(\mathrm{q} 24 ; \mathrm{q} 11), M Y C \& I G L \\
\mathrm{t}(2 ; 8)(\mathrm{p} 12 ; \mathrm{q} 24), M Y C \& I G K\end{array}$ & $>90 \%$ & FISH; karyotyping & $\begin{array}{l}\text { Breakpoints may be } \\
\text { far from } M Y C\end{array}$ & $\begin{array}{l}\text { Always co- } \\
\text { localization with } \\
\text { IG loci: FISH } \\
\text { assays for } 8 \mathrm{q} 24 \\
\text { split and } M Y C-I G \\
\text { fusion } \\
\text { recommended }\end{array}$ & \\
\hline \multirow[t]{2}{*}{$\begin{array}{l}\text { Diffuse large B cell } \\
\text { lymphoma NOS }\end{array}$} & $\mathrm{t}(3)(\mathrm{q} 27) ; B C L 6$ & $30-40 \%$ & FISH; karyotyping & $\begin{array}{l}\text { karyotype may show } \\
\text { very complex } \\
\text { abnormalities and } \\
\text { multiple subclones }\end{array}$ & & $\begin{array}{l}\text { BCL6 mutations in } \\
\text { majority of cases }\end{array}$ \\
\hline & $\mathrm{t}(8)(\mathrm{q} 24), M Y C$ & $5-20 \%$ & FISH; karyotyping & $\begin{array}{l}\text { In } 40 \% M Y C \text { is not } \\
\text { juxtaposed to IG } \\
\text { locus but to a variety } \\
\text { of other partners }\end{array}$ & $\begin{array}{l}>50 \% \text { are double } \\
\text { hit lymphomas and } \\
\text { likely should be } \\
\text { diagnosed as B cell }\end{array}$ & $\begin{array}{l}\text { Associated with } \\
\text { poor survival }\end{array}$ \\
\hline
\end{tabular}




\begin{tabular}{|c|c|c|c|c|c|}
\hline & & & & & $\begin{array}{l}\text { lymphoma } \\
\text { unclassifiable }\end{array}$ \\
\hline $\begin{array}{r}\text { Specific in ABC type } \\
\text { NOS }\end{array}$ & $\begin{array}{l}\text { Del 6q; del 9p21, CDKN2A; } \\
\text { trisomy 3, FOXP1?; +18q21, } \\
B C L 2 / N F A T C 1 ;+19 \mathrm{q}, S P I B\end{array}$ & $15-35 \%$ & aCGH; FISH & $\begin{array}{l}\text { Trisomy } 3 \text { and del } \\
\text { 9p21 associated with } \\
\text { poor survival }\end{array}$ & $\begin{array}{l}\text { Subtype } \\
\text { distinguished by } \\
\text { IHC algorithm }^{71}\end{array}$ \\
\hline \multirow[t]{2}{*}{$\begin{array}{r}\text { Specific in GCB } \\
\text { type NOS }\end{array}$} & $\mathrm{t}(14 ; 18)(\mathrm{q} 32 ; \mathrm{q} 21), B C L 2 \& I G H$ & & FISH; karyotyping & $\begin{array}{l}\text { Associated with } \\
\text { CD10 and BCL2 } \\
\text { protein expression }\end{array}$ & $\begin{array}{l}\text { Subtype } \\
\text { distinguished by } \\
\text { IHC algorithm }^{71}\end{array}$ \\
\hline & Del 1p, TP73; amp 2p, REL & & aCGH; FISH & & \\
\hline $\begin{array}{l}\text { Primary mediastinal } \\
\text { large B cell } \\
\text { lymphoma }\end{array}$ & $\begin{array}{l}+9 \mathrm{p}, J A K 2 / P D C D 1 L G 2 ; \mathrm{amp} \\
2 \mathrm{p}, R E L\end{array}$ & $15-40 \%$ & aCGH; FISH & & \\
\hline $\begin{array}{l}\text { Primary DLBCL leg } \\
\text { type }\end{array}$ & $\begin{array}{l}\text { Similar to ABC type DLBCL } \\
\text { NOS; } \mathrm{t}(3)(\mathrm{q} 27), B C L 6 ; \mathrm{t}(8)(\mathrm{q} 24) \\
\text { or gain, } M Y C ;+18 \mathrm{q} 21 \text { or } \\
\text { amplification; del9p } 21 \text {, } \\
C D K N 2 A\end{array}$ & $30->60 \%$ & aCGH; FISH & & $\begin{array}{l}\text { Diagnosis made by } \\
\text { combination of } \\
\text { features (clinic, } \\
\text { morphology, } \\
\text { phenotype) }\end{array}$ \\
\hline DLBCL of the CNS & $\begin{array}{l}\text { Similar to ABC type DLBCL } \\
\text { NOS; t(3)(q27), BCL6; +18q21 } \\
\text { or amplification; de19p21 } \\
C D K N 2 A ; \text { del } 6 \mathrm{p} 21.3 \text { (HLA) }\end{array}$ & $\begin{array}{l}\text { See ABC type of } \\
\text { DLBCL }\end{array}$ & $\mathrm{aCGH}, \mathrm{FISH}$ & $\begin{array}{l}\text { Small deletion in } \\
\text { HLA region seem to } \\
\text { be unique for DLBCL } \\
\text { of the CNS, testis }\end{array}$ & \\
\hline $\begin{array}{l}\text { T cell/histiocyte rich } \\
\text { large B cell } \\
\text { lymphoma }\end{array}$ & No recurrent abnormalities & - & - & & \\
\hline ALK+ DLBCL & $\begin{array}{l}\mathrm{t}(2 ; 17)(\mathrm{p} 23 ; \mathrm{q} 23), \text { fusion of } \\
C L T R-A L K ; \text { rarely } \\
\mathrm{t}(2 ; 5)(\mathrm{p} 23 ; \mathrm{q} 35), \text { fusion of } N P M- \\
A L K\end{array}$ & $100 \%$ & $\begin{array}{l}\text { Immunohistochemistry } \\
\text { (ALK), FISH; RT- } \\
\text { PCR }\end{array}$ & $\begin{array}{l}\text { Most cases are } \\
\text { plasmablastic, CD20-, } \\
\text { CD79a-, CD45-, } \\
\text { CD138+, cyIg + }\end{array}$ & $\begin{array}{l}\text { Poor prognosis; } \\
\text { perhaps better in } \\
\text { children }\end{array}$ \\
\hline $\begin{array}{l}\text { Double hit } \\
\text { lymphomas }\end{array}$ & $\begin{array}{l}\mathrm{t}(8)(\mathrm{q} 24) \& \mathrm{t}(14 ; 18)(\mathrm{q} 32 ; \mathrm{q} 21) \text { or } \\
\mathrm{t}(8 ; 14 ; 21)(\mathrm{q} 24 ; \mathrm{q} 32 ; \mathrm{q} 21)\end{array}$ & $60 \%$ & FISH; karyotyping & $\begin{array}{l}\text { Mostly in elderly } \\
\text { patients; at least half } \\
\text { of all DLBCL with a } \\
\text { MYC breakpoint are } \\
\text { DH lymphoma }\end{array}$ & $\begin{array}{l}\text { Aggressive } \\
\text { behaviour, high } \\
\text { tumour load, bone } \\
\text { marrow and CNS } \\
\text { localization \& poor } \\
\text { prognosis }\end{array}$ \\
\hline
\end{tabular}




\begin{tabular}{|c|c|c|c|c|c|}
\hline & $\begin{array}{l}\mathrm{t}(8)(\mathrm{q} 24) \& \mathrm{t}(3)(\mathrm{q} 27) \text { or } \\
\mathrm{t}(3 ; 8)(\mathrm{q} 27 ; \mathrm{q} 24\end{array}$ & $<10 \%$ & FISH; karyotyping & & $\begin{array}{l}\text { Probably also poor } \\
\text { prognosis }\end{array}$ \\
\hline & $\begin{array}{l}\mathrm{t}(8)(\mathrm{q} 24) \& \mathrm{t}(14 ; 18)(\mathrm{q} 32 ; \mathrm{q} 21) \\
\& \mathrm{t}(3)(\mathrm{q} 27)\end{array}$ & $15 \%$ & FISH; karyotyping & $\begin{array}{l}\text { Also called "triple hit } \\
\text { lymphoma" }\end{array}$ & $\begin{array}{l}\text { Aggressive } \\
\text { behaviour, high } \\
\text { tumour load, bone } \\
\text { marrow and CNS } \\
\text { localization \& poor } \\
\text { prognosis }\end{array}$ \\
\hline $\begin{array}{l}\text { CLL / small } \\
\text { lymphocytic }\end{array}$ & $\begin{array}{l}\text { Del } 13 q 14.3 \text {, miRNA } 16-1 \text { and } \\
15-\mathrm{a} ?\end{array}$ & $30-50 \%$ & FISH; aCGH & $\begin{array}{l}\text { associated with } \\
\text { favourable prognosis }\end{array}$ & \\
\hline \multirow[t]{4}{*}{ lymphoma } & & 3 & & & \\
\hline & Del 11q22-23, ATM & $10-20 \%$ & FISH; aCGH & & \\
\hline & Trisomy 12 & $10-20 \%$ & FISH; aCGH & $\begin{array}{l}\text { associated with } \\
\text { atypical CLL }\end{array}$ & \\
\hline & Del 17p13, TP53 & $10 \%$ & FISH; aCGH & $\begin{array}{l}\text { associated with } \\
\text { extremely poor } \\
\text { prognosis }\end{array}$ & \\
\hline $\begin{array}{l}\text { Splenic marginal } \\
\text { zone lymphoma }\end{array}$ & Del 7q31-32, CDK6? & $40 \% ?$ & FISH; aCGH & $\begin{array}{l}\text { no prognostic } \\
\text { significance }\end{array}$ & \\
\hline \multirow[t]{4}{*}{$\begin{array}{l}\text { MALT marginal } \\
\text { zone lymphomas }\end{array}$} & $\begin{array}{l}\mathrm{t}(11 ; 18)(\mathrm{q} 21 ; \mathrm{q} 21), A P I 2 \& \\
M A L T 1\end{array}$ & $\begin{array}{l}5-30 \% \text { of gastric } \\
\text { and } 30-50 \% \text { of } \\
\text { pulmonary MALT } \\
\text { lymphomas }\end{array}$ & RT-PCR, FISH & $\begin{array}{l}\text { Associated with } \\
\text { resistance to HP } \\
\text { eradication therapy }\end{array}$ & \\
\hline & $\begin{array}{l}\mathrm{t}(14 ; 18)(\mathrm{q} 32 ; \mathrm{q} 21), I G H \& \\
M A L T 1\end{array}$ & $\begin{array}{l}0-20 \% \text { of ocular } \\
\& \text { salivary MALT } \\
\text { lymphomas }\end{array}$ & FISH & & \\
\hline & $\mathrm{t}(1 ; 14)(\mathrm{p} 22 ; \mathrm{q} 32), B C L 10 \& I G H$ & $\begin{array}{l}<10 \% \text { in all } \\
\text { MALT } \\
\text { lymphomas }\end{array}$ & FISH & & \\
\hline & Trisomy 3 & $\begin{array}{l}\text { Up to } 50 \% \text { in all } \\
\text { MALT }\end{array}$ & & & \\
\hline
\end{tabular}




\section{lymphomas}

\begin{tabular}{|c|c|c|c|c|}
\hline $\begin{array}{l}\text { Nodal marginal zone } \\
\text { lymphoma }\end{array}$ & $\begin{array}{l}\text { No specific abnormality } \\
\text { (trisomies) }\end{array}$ & - & - & \\
\hline $\begin{array}{l}\text { Lymphoplasmacytic } \\
\text { lymphoma }\end{array}$ & Del 6q & $40-60 \% ?$ & FISH; aCGH & $\begin{array}{l}\text { No prognostic } \\
\text { significance }\end{array}$ \\
\hline Hairy cell leukemia & No specific abnormality & - & - & \\
\hline \multicolumn{5}{|c|}{ T-cell lymphomas } \\
\hline \multirow[t]{3}{*}{$\begin{array}{l}\text { T-cell } \\
\text { prolymphocytic } \\
\text { leukemia }\end{array}$} & $\begin{array}{l}\mathrm{t}(14 ; 14)(\mathrm{q} 11 ; \mathrm{q} 32) \text { or inversion, } \\
T C R A \& T C L 1 B ; \\
\mathrm{t}(\mathrm{X} ; 14)(\mathrm{q} 28 ; \mathrm{q} 11), M T C P 1 \& \\
T C R A\end{array}$ & $80-100 \%$ & karyotyping & \\
\hline & $\begin{array}{l}\text { Abn } 8 \mathrm{p} 11 \text { and } \mathrm{t}(8 ; 8)(\mathrm{p} 11- \\
12 ; \mathrm{q} 12)\end{array}$ & $80 \%$ & karyotyping & \\
\hline & Del 11q23, ATM & & Karyotyping; FISH & \\
\hline $\begin{array}{l}\text { T-cell large granular } \\
\text { lymphocyte } \\
\text { leukemia }\end{array}$ & No specific abnormality & - & - & \\
\hline $\begin{array}{l}\text { Extra nodal } \mathrm{NK} / \mathrm{T} \\
\text { cell lymphoma, } \\
\text { nasal type }\end{array}$ & $\operatorname{Del}(6)(\mathrm{q} 21 \mathrm{q} 25)$ or $\mathrm{i}(6)(\mathrm{p} 10)$ & & $\begin{array}{l}\text { aCGH, karyotyping, } \\
\text { metaphase FISH }\end{array}$ & \\
\hline $\begin{array}{l}\text { Enteropathy } \\
\text { associated T cell } \\
\text { lymphoma, type A } \\
\end{array}$ & $\begin{array}{l}+9 \mathrm{q} 31.3 ; \text { del16q12; +1q31-q41; } \\
+5 \mathrm{qq} 34-\mathrm{q} 35\end{array}$ & $80 \%$ & $\mathrm{aCGH}$ & $\begin{array}{l}\text { CD3+, CD8-, CD56-, } \\
\text { CD30+ in }>50 \%\end{array}$ \\
\hline $\begin{array}{l}\text { Enteropathy } \\
\text { associated T cell } \\
\text { lymphoma, type B }\end{array}$ & $+9 \mathrm{q} 31.3 ;$ del16q12; +8q24; $M Y C$ & $80 \%$ & $\mathrm{aCGH}$ & $\mathrm{CD} 3+, \mathrm{CD} 8+, \mathrm{CD} 56+$ \\
\hline $\begin{array}{l}\text { Hepatosplenic T- } \\
\text { cell lymphoma }\end{array}$ & Abn \#7, incl ring chromosome 7 & & $\begin{array}{l}\text { Karyotyping, } \\
\text { metaphase FISH }\end{array}$ & \\
\hline $\begin{array}{l}\text { Angioimmunoblastic } \\
T \text { cell lymphoma }\end{array}$ & Trisomy 3,5 & & $\mathrm{aCGH}$ & \\
\hline Peripheral T cell & Many imbalances incl gains at & & $\mathrm{aCGH}$ & \\
\hline
\end{tabular}




\begin{tabular}{|c|c|c|c|c|c|}
\hline lymphoma NOS & $7 \mathrm{q}, 8 \mathrm{q}, 17 \mathrm{q}$, losses at $4 \mathrm{q}, 5 \mathrm{q}, 6 \mathrm{q}$ & & & & \\
\hline $\begin{array}{l}\text { Anaplastic large cell } \\
\text { lymphoma ALK+ }\end{array}$ & $\begin{array}{l}\mathrm{t}(2 ; 5)(\mathrm{p} 23 ; \mathrm{q} 35), \text { fusion of } N P M \\
\& A L K ; \text { many other variant } \\
\text { translocations involve } A L K \text { at } \\
2 \mathrm{p} 23 \text { (fusion) }\end{array}$ & $\begin{array}{l}\mathrm{t}(2 ; 5) \text { in } 85 \% \\
\text { variants in } 15 \%\end{array}$ & $\begin{array}{l}\text { Immunohistochemistry } \\
\text { for ALK; FISH, RT- } \\
\text { PCR }\end{array}$ & $\begin{array}{l}\text { IHC pattern can } \\
\text { reveal fusion gene of } \\
A L K \text { (e.g. NPM: } \\
\text { nuclear and } \\
\text { cytoplasmic; } C L T R \\
\text { granular cytoplasmic) }\end{array}$ & $\begin{array}{l}\text { Better prognosis } \\
\text { than ALK negative } \\
\text { ALCL }\end{array}$ \\
\hline $\begin{array}{l}\text { Anaplastic large cell } \\
\text { lymphoma ALK- }\end{array}$ & $\begin{array}{l}\text { No translocations involving } \\
A L K \text {; many imbalances }\end{array}$ & & $\begin{array}{l}\text { Immunohistochemistry } \\
\text { for ALK; FISH, RT- } \\
\text { PCR }\end{array}$ & $\begin{array}{l}\text { Worse prognosis than } \\
\text { ALK positive ALCL }\end{array}$ & \\
\hline
\end{tabular}

*: Rare disorders, cutaneous lymphomas, EBV, HTLV1 and HHV8 associated lymphoproliferative disorders excluded

blue: diagnosis that more or less is defined by its genetic abnormality (or the associated immunohistochemical marker); yellow: genetic abnormality is important prognostic abnormality in clinical setting 


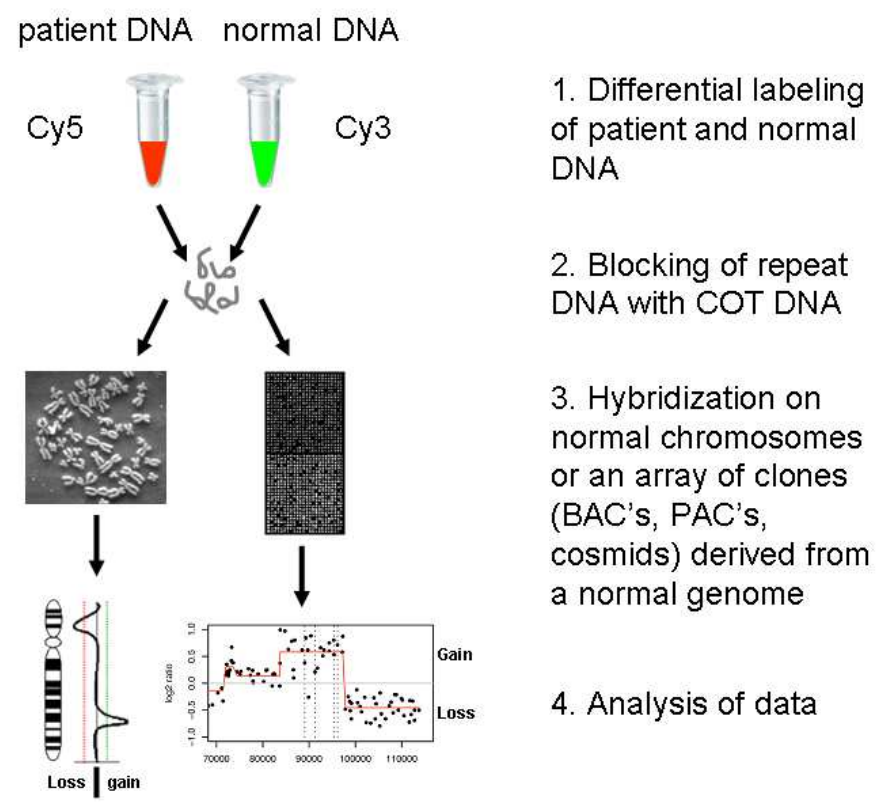

Figure 1. Principles of conventional $\mathrm{CGH}$ and array $\mathrm{CGH}$.

Normal DNA and tumor DNA are differentially labeled, often with Cy3 and Cy5. After blocking of (ubiquitously present and thus hindering) repetitive DNA, these labeled DNAs are competitively hybridized to either normal chromosome preparations or a high density array of (preferably) overlapping probes on a glass slide. In case of conventional $\mathrm{CGH}$, the preparations can be directly analyzed on a fluorescence microscope, in cases of an array, dedicated hardware (a microarray scanner) and software is necessary.

254x190mm (96 x 96 DPI) 

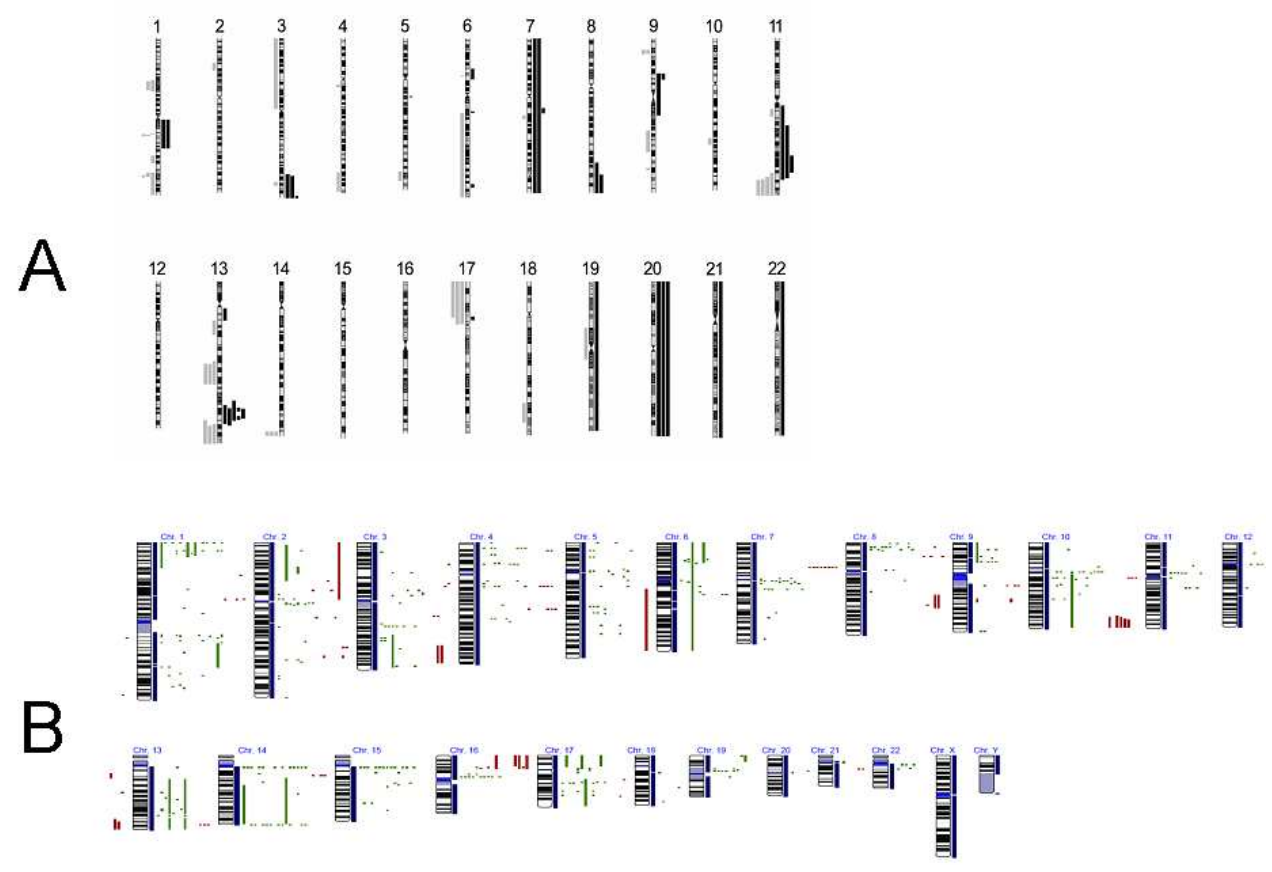

Figure 2. Array CGH analysis and SNP analysis of pediatric Burkitt lymphoma.

Panel A shows conventional CGH analysis of a series of 15 paediatric Burkitt lymphomas is show. Each black bar to the right of a chromosome represents gain in an individual case; each grey bar to the left side of a chromosome represents loss. This analysis shows a limited number of recurrent aberrations, such as copy number increase of chromosome 13q31-32 and loss of chromosome 17p.

Panel B shows a SNP analysis of 18 paediatric Burkitt lymphomas is shown. The human CNV370DUO BeadChips (Illumina Inc, San Diego, CA, USA) array was used. SNP array data were imported into BeadStudio (Illumina Inc, San Diego, CA, USA) and analyzed using the Chromozone bookmark plug-in and a modified version of SOMATICs. Directly to the right of each chromosome, the black bar indicates the region that is covered by the probes. Gains are indicated by green bars richt of the chromosomes, losses by red bars (left of the chromosome). Note the higher resolution but also the higher complexity, with in particular a larger number of smaller events, in particular around the centromeres of chromosomes. A large number of these alterations reflect copy number variations between individuals and are not tumour specific.

Panel C shows a case analyzed by SNP's with a small homozygous deletion on 9p21, containing only the CDKNBA and CDKN2B genes. In a second case (not shown) there was a large hemizygous deletion and a similar small deletion on the other allele. These small deletions were not detected by either conventional $\mathrm{CGH}$ or array $\mathrm{CGH}$ (data not shown).

$254 \times 190 \mathrm{~mm}(96 \times 96$ DPI) 


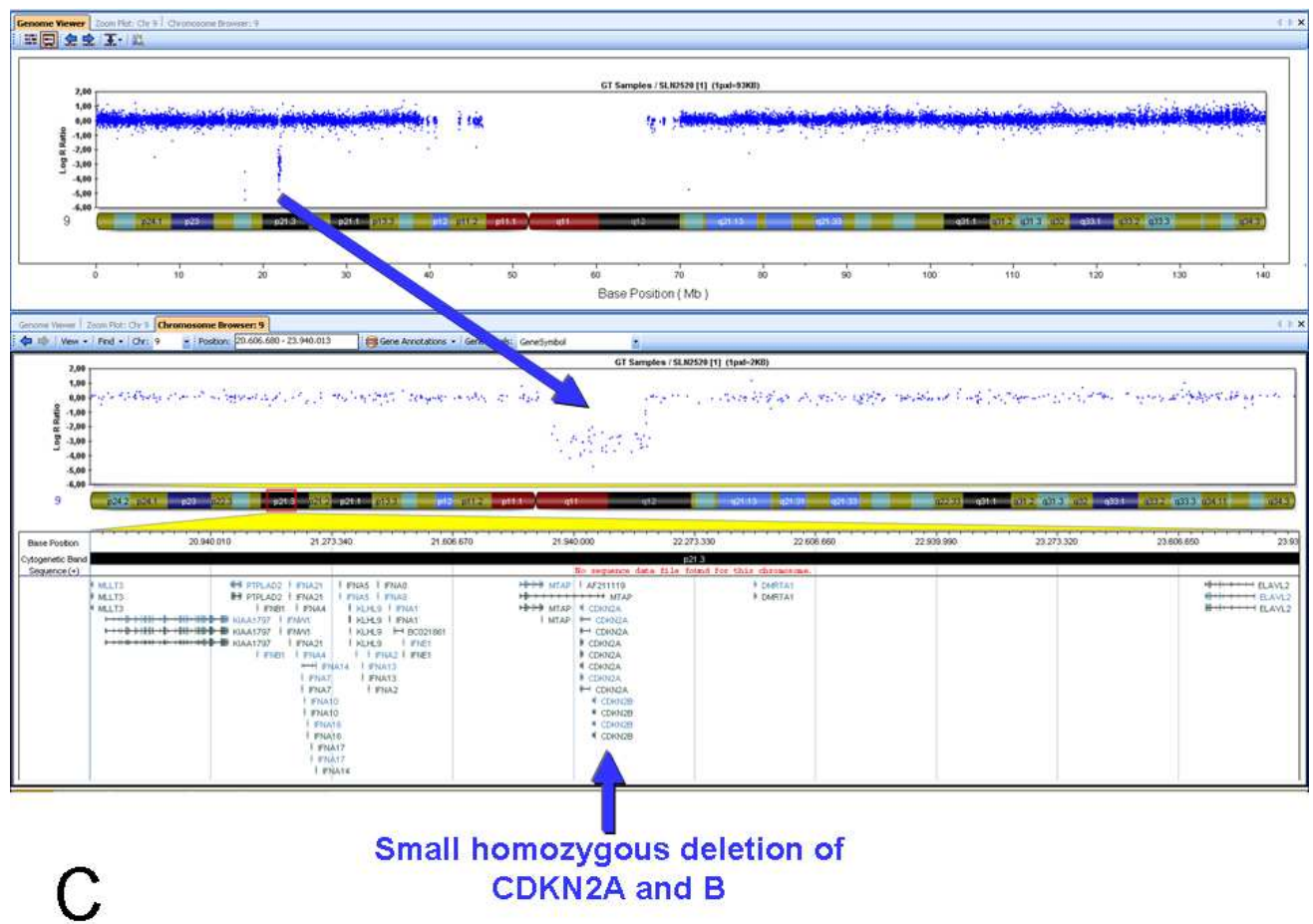

Figure 2. Array CGH analysis and SNP analysis of pediatric Burkitt lymphoma.

Panel A shows conventional CGH analysis of a series of 15 paediatric Burkitt lymphomas is show. Each black bar to the right of a chromosome represents gain in an individual case; each grey bar to the left side of a chromosome represents loss. This analysis shows a limited number of recurrent aberrations, such as copy number increase of chromosome 13q31-32 and loss of chromosome 17p.

Panel B shows a SNP analysis of 18 paediatric Burkitt lymphomas is shown. The human CNV370DUO BeadChips (Illumina Inc, San Diego, CA, USA) array was used. SNP array data were imported into BeadStudio (Illumina Inc, San Diego, CA, USA) and analyzed using the Chromozone bookmark plug-in and a modified version of SOMATICs. Directly to the right of each chromosome, the black bar indicates the region that is covered by the probes. Gains are indicated by green bars richt of the chromosomes, losses by red bars (left of the chromosome). Note the higher resolution but also the higher complexity, with in particular a larger number of smaller events, in particular around the centromeres of chromosomes. A large number of these alterations reflect copy number variations between individuals and are not tumour specific.

Panel C shows a case analyzed by SNP's with a small homozygous deletion on 9p21, containing only the CDKNBA and CDKN2B genes. In a second case (not shown) there was a large hemizygous deletion and a similar small deletion on the other allele. These small deletions were not detected by either conventional CGH or array CGH (data not shown).

$254 \times 190 \mathrm{~mm}(96 \times 96 \mathrm{DPI})$ 


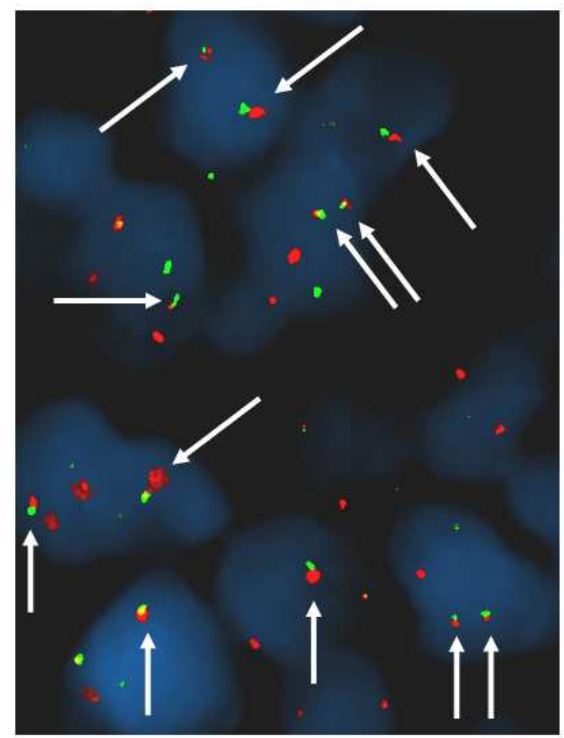

Figure 3. Colocalization of MYC and IGH in Burkitt lymphoma.

A case of paediatric Burkitt lymphoma with presentation in the tonsil with a MYC-break (detected with the Vysis LSI MYC Dual Color, Break Apart Rearrangement Probe set from Abbott molecular; data not shown), was hybridized with the Vysis LSI IGH/MYC, CEP 8 Tri-color, Dual Fusion Translocation Probe. Many cells show fusion of the MYC (green) and IGH (red) signals (arrows). Note that the percentage of spurious co-localizing signals can be high in normal cells, up to $20 \%$ of all cells.

$254 \times 190 \mathrm{~mm}(96 \times 96 \mathrm{DPI})$ 